\title{
THE ZYGOSITY DETERMINATION OF JAPANESE TWINS USING A MINISATELLITE CORE PROBE
}

\author{
Kazuyoshi Motomura, ${ }^{1}$ Hideo Tateishi, ${ }^{1}$ Isamu Nishisho, ${ }^{1}$ \\ Makoto Okazaki, ${ }^{1}$ Tetsuro Miki, ${ }^{2}$ Akira Tonomura, ${ }^{3}$ \\ Shin-ichiro TAKAI, ${ }^{1}$ Takesada MORI, ${ }^{1}$ and \\ Alec J. JEFFrEYs ${ }^{4}$ \\ ${ }^{1}$ Second Department of Surgery, ${ }^{2}$ Department of Medicine and Geriatrics, Osaka \\ University Medical School, Fukushima-ku, Osaka 553, Japan \\ ${ }^{2}$ Department of Cytogenetics, Medical Research Institute, Tokyo Medical \\ and Dental University, Bunkyo-ku, Tokyo 113, Japan \\ ${ }^{4}$ Department of Genetics, University of Leicester, University \\ Road, Leicester LEI $7 R H, U K$
}

\begin{abstract}
Summary Hypervariable 'minisatellite' regions which are dispersed in the human genome show restriction fragment length polymorphisms (RFLPs) due to allelic differences in the number of tandem repeats containing the core sequence. Southern blot hybridization using minisatellite core probes produces various band patterns, which are completely individual-specific and of which few fragments are shared between two randomly selected individuals. If the band patterns are identical between twins, they must be monozygotic. We report here the use of minisatellite core probe for zygosity determination in five Japanese twin pairs and in a set of triplets.
\end{abstract}

\section{INTRODUCTION}

In Japan, twinning rates were estimated to be $0.64 \%$ and using Weinberg's method monozygotic twinning rate was about $0.4 \%$ (Kamimura, 1976). There have been many methods to determine zygosity such as assessment of the general appearance, fingerprints, sex, skin grafts, placental structure and conventional genetic markers (Inoue, 1956; Asaka, 1976).

Recently, Derom et al. (1985) reported the method for zygosity determination using single copy human DNA probes which can detect RFLPs due to base substitutions.

Conventional genetic markers and DNA variants can accurately determine

Received January 6, 1987; Accepted February 6, 1987 
twin zygosity, but many markers must be investigated because most of them are dimorphic. Minisatellites containing vario.s number of tandem repeats show highly polymorphic band patterns which are individual-specific and inherited in a Mendelian fashion (Jeffreys et al., 1985). Since many sites in the genome can be cxamined at a time with a minisatellite core probe, twin zygosity can be determined in a single experiment (Hill and Jeffreys, 1985).

\section{MATERIALS AND METHODS}

I) DNA isolation. Heparinized peripheral or umbilical cord blood samples (usually 3-20 ml) were obtained from eight unrelated Japanese, a Japanese family of three generations, five pairs of twins and a set of triplets. DNA was extracted from white blood cells as described elsewhere (Nishisho et al., 1986). In one individual (Fig. 3, individual 7), DNA was extracted from lymphoblastoid cell lines transformed by Epstein-Barr virus on the ground that the band patterns detected by the probe 33.15 appear stable in cultured cells (Jeffreys et al., 1985).

2) Restriction enzyme digestion and DNA blotting. 5-10 $\mu \mathrm{g}$ of DNA were digested with HinfI, electrophoresed through a $20 \mathrm{~cm}-0.6 \%$ agarose gel and trans-

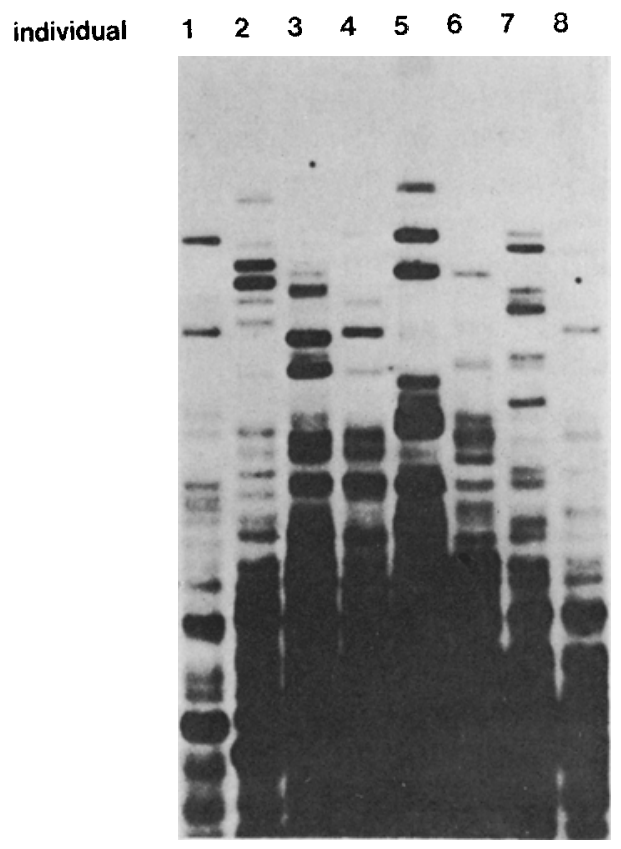

Fig. 1. Individual specific DNA band patterns. Double-stranded minisatellite core probe 33.15 was used as a hybridization probe on Southern transfer of HinfI digested DNA from eight unrelated individuals. 
ferred to a nitrocellulose filter by the method of Southern (Southern, 1975). After transfer, filters were baked under vacuum at $80^{\circ} \mathrm{C}$ for $3 \mathrm{hr}$.

3) Hybridization probe. Replication form double stranded DNA was prepared from single stranded M13 recombinant DNA (233.15) and digested with Eco RI and HindIII, the resulting fragments were resolved by electrophoresis in $0.7 \%$ agarose gels. The EcoRI-HindIII fragments containing the minisatellite from $\lambda 33.15$ were extracted and labeled with $\left[{ }^{32} \mathrm{P}\right] \alpha$-dCTP by multiprime DNA labeling system (Amersham, England) to specific activities of at least $1.8 \times 10^{9} \mathrm{cpm} / \mu \mathrm{g}$. ${ }^{32} \mathrm{P}-\mathrm{Labeled}$ probes were hybridized to genomic blots at $65^{\circ} \mathrm{C}$ for $15-20 \mathrm{hr}$ in $1 \times$ Denhardt's solution, $1 \mathrm{M} \mathrm{NaCl}, 50 \mathrm{~mm}$ Tris- $\mathrm{HCl}$ (pH 7.4), $10 \mathrm{~mm}$ EDTA, $0.1 \%$ SDS and 0.1 $\mathrm{mg} / \mathrm{ml}$ denatured sonicated salmon sperm DNA. Filters were washed once at room temperature in $2 \times \mathrm{SSC}$ and twice at $65^{\circ} \mathrm{C}$ in $1 \times \mathrm{SSC}, 0.1 \% \mathrm{SDS}$ for $30 \mathrm{~min}$.

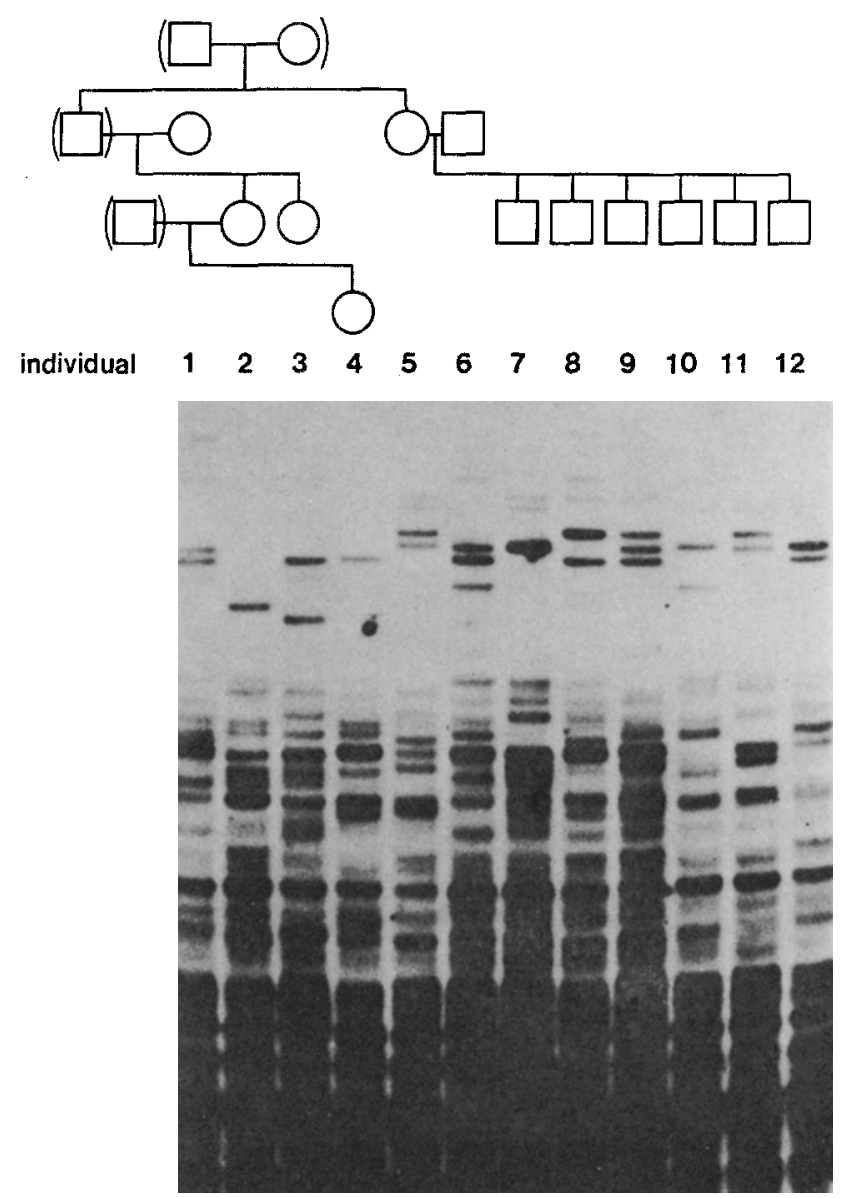

Fig. 2. Inheritance of polymorphic alleles detected by probe 33.15 in a Japanese family of three generations. 
The filters were exposed to XRP-1 film (Kodak) backed by a Lightning Plus intensifying screen (Dupont) at $-80^{\circ} \mathrm{C}$ for $2-6$ days.

\section{RESULTS}

Figure 1 shows individual specificity of band patterns of eight unrelated Japanese. Four to twenty kb HinfI fragments can be resolved and shared bands are few between randomly selected pairs of individuals.

HinfI polymorphic fragments are inherited and segregate in a Mendelian fashion as shown in Fig. 2. Even in a family, sibs do not share all the polymorphic fragments.

case

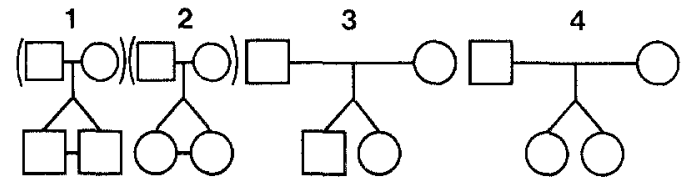

$\begin{array}{lllllllllllll}\text { individual } & 1 & 2 & 3 & 4 & 5 & 6 & 7 & 8 & 9 & 10 & 11 & 12\end{array}$

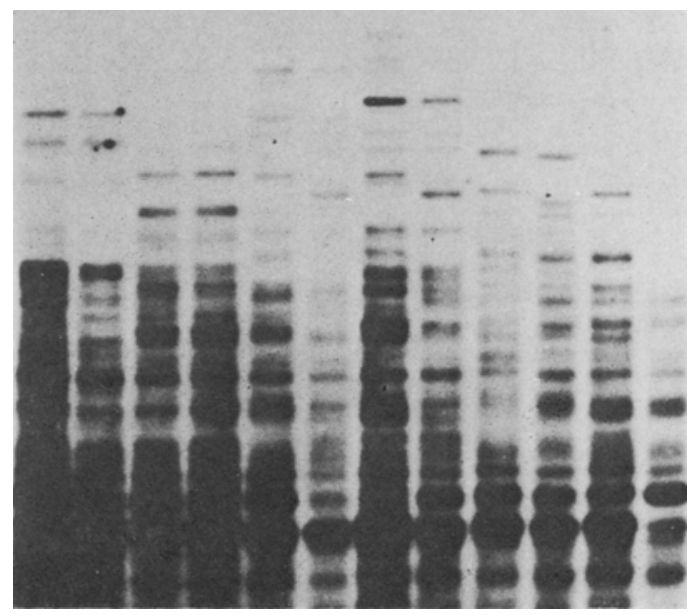

Fig. 3. Hybridization band patterns obtained by probe 33.15 in four pairs of twins.

Table 1. Results of zygosity determination by minisatellite core probe 33.15 and conventional genetic markers.

\begin{tabular}{clll} 
Case & Sex & Band pattern & $\begin{array}{c}\text { Conventional } \\
\text { genetic markers }\end{array}$ \\
I & MM & Identical & Identical \\
2 & FF & Identical & Identical \\
3 & MF & Non-identical & Not done \\
4 & FF & Non-identical & Non-identical \\
5 & FF & Identical & Identical \\
6 & MMF & Non-identical & Not done \\
\hline
\end{tabular}


Figure 3 presents DNA band patterns of four out of five pairs of twins. In case 3, the twins were of different sex, and they were dizygotic. In other four cases (case 1, 2, 4, 5) they were of the same sex and unclear about their zygosity (Table 1). In three cases (case 1,2,5), the twins had identical band patterns suggesting they are monozygotic. In the remaining one case (case 4), different band patterns indicated dizygosity. These results were in good agreement with the data obtained by analysis with about 30-40 types of conventional genetic markers (Tabie 1).

A set of triplets was also investigated. DNA patterns were non-identical and they must be trizygotic.

\section{DISCUSSION}

Quite a number of conventional genetic markers and DNA variants must be investigated for accurate determination of twin zygosity. As the probability that all fragments detected by the probe 33.15 in sib A also present in sib B in a single family is $3 \times 10^{-5}$ (Jeffreys et al., 1985), this probe can singly and correctly determine the twin zygosity. In addition to this probe 33.15 , use of the probe 33.6 can determine zygosity more accurately $\left(\sim 10^{-8}\right)$ (Jeffreys et al., 1985). But it was enough for zygosity determination to use a single probe 33.15 .

In this method, small amounts of umbilical cord blood suffice to zygosity determination at birth which is important to assess the prognosis of twins.

This method will be also useful for the investigation of the multiple pregnancy which goes on increasing by the use of fertility drugs.

In addition, the minisatellite core probe may be able to detect specific band in close linkage with disease locus in large families at high risk for hereditary diseases. This probe will be also applied to compare the constitutional and tumor DNA of the patients to detect loss of heterozygosity in tumor DNA which might be responsible for tumorigenesis.

Acknowledgment We are grateful to Dr. T. Ikeuchi, Dr. T. Iwama, Dr. T. Hara and Dr. Y. Inoue for helping us to collect blood samples and cultured cells. We also thank Dr. H. Matsumoto for analysis of conventional genetic markers. We also wish to thank Ms. M. Matsumoto and Ms. Y. Aihara for technical assistance. This study was supported by Grant-in-Aid for Cancer Research, and Grant-in-Aid for Special Project Research, Cancer-Bioscience, from the Ministry of Education, Science and Culture of Japan. The minisatellite probes are the subject of Patent Applications. Commercial inquiries should be addressed to the Lister Institute of Preventive Medicine, Royal National Orthopaedic Hospital, Brockley Hill, Stanmore, Middlesex HA7 4LP, U.K.

\section{REFERENCES}

Asaka, A. 1976. The zygosity diagnosis of Japanese twins by dermatoglyphic features. Jpn. $J$. Human Genet. (in Japanese with English summary) 21 : 131-142.

Derom, C., Bakker, E., Vlietinck, R., Derom, R., Van den Berghe, H., Thiery, M., and Pearson, P. 1985. Zygosity determination in newborn twins using DNA variants. J. Med. Genet. 22: 279-282. 
Hill, A.V.S. and Jeffreys, A.J. 1985. Use of minisatellite DNA probes for determination of twin zygosity at birth. Lancet 1985 I: 1394-1395.

Inoue, E. 1956. A review on the zygosity diagnosis of twins. Jpn. J. Human Genet. (in Japanese with English summary) 1: 24-31.

Jeffreys, A.J., Wilson, V., and Thein, S.L. 1985. Hypervariable 'minisatellite' regions in human DNA. Nature 314: 67-73.

Jeffreys, A.J., Wilson, V., and Thein, S.L. 1985. Individual-specific "fingerprints" of human DNA. Nature 316: 76-79.

Kamimura, K. 1976. Ecological aspects on the twin birth. Niigata Med. $J$. (in Japanese) 90: 293-298.

Nishisho, I., Miki, T., Tateishi, H., Takai, S., Motomura, K., Nakura, J., Kumahara, Y., Mori, T., and Honjo, T. 1986. Isolation of DNA clones revealing restriction fragment length polymorphisms in the human genome. Jpn. J. Human Genet. $31: 249-258$.

Southern, E.M. 1975. Detection of specific sequences among DNA fragments separated by gel electrophoresis. J. Mol. Biol. 98: 503-517. 